\title{
28 Research Soure \\ Dengue Vector Density Incident and Its Implication to Urban Livability
}

Nuriah Abd Majid ( $\nabla$ nuriah@ukm.edu.my )

Universiti Kebangsaan Malaysia https://orcid.org/0000-0002-6199-2299

Muhammad Rizal Razman

Universiti Kebangsaan Malaysia

Sharifah Zarina Syed Zakaria

Universiti Kebangsaan Malaysia

Nurafiqah Muhamad Nazi

Universiti Kebangsaan Malaysia

Research article

Keywords: Dengue, Land use, Livability - urban density, GIS

Posted Date: June 25th, 2020

DOl: https://doi.org/10.21203/rs.3.rs-33464/v1

License: (c) (1) This work is licensed under a Creative Commons Attribution 4.0 International License.

Read Full License 


\section{Abstract}

Background: Malaysia's population is set to reach 33.10 million by the end of 2020 . About $75 \%$ of the population of Malaysia lived in urban areas and cities. The metropolitan area of Greater Kuala Lumpur had a population of more than seven million that year, making it the largest urban area in Malaysia. Kuala Lumpur as the city centre for Greater Kuala Lumpur has been ranked as Southeast Asia's second most liveable city after Singapore. The livable city imperative is relevant because Malaysia's urbanization process is moving towards harmonization with the principles of sustainable development. Livable city involves many interdependent factors contributing to the urban quality of life. With their complete physical and social infrastructures, the urban types are an essential basis for improving the quality of life of the urbanites. However, increasing population and rapid land-use changes led to the emergence of vector-borne diseases such as dengue in an urban area. Prolong dengue outbreaks will reduce livability in urban areas. Therefore, this study aims to look at the density of dengue distribution in Bandar Baru Bangi town in 2014, 2015, 2016 and 2017.

Methods: The study uses data provided from the Ministry of Health Malaysia and shows the focus of dengue cases in residential and industrial areas of Bandar Baru Bangi town. Spatial analysis using Geographical Information System (GIS) was applied to identify the locality of dengue incidence within the study area. Spatial statistical analysis of dengue cases used Kernel Density Estimation to distinguish dengue hotspots from the distribution of the exact location of dengue cases reported in Bandar Baru Bangi town.

Results: Kernel density estimation showed the dengue hotspots concentrated on the east of Bandar Baru Bangi town. The results found that the highest density was in 2015 was 605 to 706 points per square kilometres. This study also discovers that most of the hotspots constructed were located in the residential area of Bandar Baru Bangi.

Conclusions: This study is essential to help local authorities eradicate dengue in urban areas for future management strategies; therefore, this study is vital to help local authorities eradicate dengue in urban areas for future management strategies.

\section{Background}

When people live in a location with a generally clean, healthy, stable and safe environment, that place can be categorized as livable [1]. In the post-independence era, more Malaysians have migrated to urban areas seeking a better life. Kuala Lumpur, as a developing city, offers many job opportunities to cater to the urban population. Thus, it has to transform Kuala Lumpur into a city with a high population density. Furthermore, urban areas such as Kuala Lumpur, also provide numerous facilities and services in various sectors, including education, transport, health and communication. Every year, a growing population causes urban areas into becoming more compact, and gradually creates satellite cities around Kuala 
Lumpur, namely Greater Kuala Lumpur or also known as Klang Valley. Situated on the outskirts of Kuala Lumpur, several districts of Selangor State such as Shah Alam, Petaling Jaya, Klang, Subang Jaya, Selayang, Ampang Jaya, Sepang, and Kajang that made up Greater Kuala Lumpur are developing gradually as these cities provide a pleasant and more spacious residential area [2].

Malaysia has experienced a rapid expansion of the neighbourhood, especially in urban areas since the 1970s due to the rapid cycle of urbanization [3]. The major driving forces for housing demand and development are shifts in demographics, land availability and suitability. Therefore, urban liveability can be defined as a sustainable and harmonious way of developing economic, financial, cultural, land use and the environment in cities [4]. A liveable city, from urban planning and land use, is a community with a sufficient set of good living conditions (both natural and cultural) and appropriate patterns of land use that meet the needs of residents [5].

While rapid urbanization has brought tremendous changes to the urban landscape, scholars also noted the increase in outbreaks of vector-borne infectious disease, the dengue fever in these satellite cities [618]. Dengue fever is one of the world's most rapidly spreading mosquito-borne viral infections caused by closely related dengue viruses. There was about 1.2 million dengue fever reported around the world in 2008, which then rose to 3.34 million cases in 2016 [19]. According to a statistic by Ministry of Health Malaysia, 130,101 dengue fever cases were reported for the year 2019 and caused 182 deaths in Malaysia [20]. However, dengue fever cases show a significant decline in March 2020 where there are 34,238 cases reported cumulatively compared to the same week on last year (March 2019) with 36,285 dengue fever cases have been reported [21]. Dengue is predominantly an urban disease in Malaysia, and Selangor is the area that has been primarily affected by the disease with a large number of cases [22].

The increase in vector density can be attributed to heavy monsoon and hot, humid weather driven by the area's construction activities, urbanization, population growth, ecological and environmental changes [23]. It is observed that the main dengue vectors are active via Aedes mosquitoes when the temperature in the surrounding area is below $28^{\circ} \mathrm{C}$. Aedes mosquitoes also need clean stagnant water to reproduce and lay eggs [24]. Female Aedes aegypti lay eggs usually on the interior walls of artificial containers. When the containers are filled with water, the eggs hatch for the mosquito larvae. An Aedes mosquito's egg will hatch into a larva in less than a day under optimal conditions. After about four days, the larva develops into a pupa, from which an adult mosquito emerges after two days.

The Aedes mosquitoes used to live with people and reside within and outside the home. The dengue virus is known to spread rapidly due to the high adaptive pattern of the Aedes species with climate change, common areas suitable as breeding sites, functional population mobility and international trade [25]. With high population density, the urban area is concentrated with on-going construction, abundant land, and field, provided a suitable habitat for Aedes mosquitoes. Thus, this situation resulted in dengue disease also one of the leading health problems in Bandar Baru Bangi town, located within the state of Selangor [26]. Through GIS, dengue outbreaks mapping within Bandar Baru Bangi town can be built. Spatial mapping that uses point data can indicate areas affected by dengue incidence. 
The surveillance of epidemic spread using GIS mapping is slowly becoming relevant for disease control and management [27]. Spatial-temporal analysis techniques are useful for measuring, assessing, and interpreting the dengue outbreak in the urban area [22]. Geo-processing and digital modelling methods have been implemented over the years to analyze public health issues and to use spatial analysis tools to interpret the spatial distribution patterns of epidemiological data [28].

The purpose of this study is to evaluate the density of dengue cases and to determine the type of land use in the Bandar Baru Bangi area to contribute to the effective decision-making process for the control of dengue outbreaks. ArcMap version 10.5 of the Geographic Information System (GIS) software was used to analyze and visualize the density using the Kernel Density tools. The Kernel Density tool calculates the density of features around those features in a neighbourhood. It can be calculated for features of both points and lines [29]. The application of this knowledge would reinforce the system of disease surveillance and enhance human resilience in urban areas.

\section{Methods}

\section{Case Study}

This study is located in the Bandar Baru Bangi town, which is a part of Kajang Municipal Council within the state of Selangor, Malaysia with coordinates $2^{\circ} 55^{\prime} 20.6^{\prime \prime} \mathrm{N}$ and $101^{\circ} 46^{\prime} 50.6^{\prime \prime} \mathrm{E}$. Located $38 \mathrm{~km}$ south of Kuala Lumpur, Bandar Baru Bangi has been growing steadily as this town becomes favourable for urban dwellers to resides (Figure 1) [30]. The total area of Bandar Baru Bangi is 2243 hectares and the total population of 4811 [31]. The average temperature in Bandar Baru Bangi is $27^{\circ} \mathrm{C}$, and its annual rainfall is $2302 \mathrm{~mm}$. Bandar Baru Bangi is a small town situated the south of Hulu Langat district and surrounded by palm oil estates which were converted to township over the last two decades. Bandar Baru Bangi emerged as land developing areas for housing estates which resulted in the growth of population density. Along with the rise of development growth, dengue epidemiology needs to be controlled to reduce the vulnerability of urban populations towards the outbreaks [32]. Bandar Baru Bangi town was listed as dengue hotspot ever since the year 2010, and this situation raised as a matter of concern for this study [33].

\section{Data Collection}

A complete dataset of cases regarding dengue fever reported from hospitalized patients of every government and private hospital within Bandar Baru Bangi town from the Ministry of Health Malaysia in the years 2014 to 2017. Dengue cases reported in Bandar Baru Bangi shown in Table 1 are 1255 cases in 2014, 1968 cases in 2015, 1407 cases in 2016 and 1687 cases in 2017. Complete demographic data is essential for GIS mapping.

Land use data obtained from the local authority and reclassified according to the relevance of the study. There are five land-use type includes built-up area, agriculture, shrub/ secondary forest, transportation and water body [34]. 


\section{Statistical Analysis}

The Kernel Density method measures the density of features around point features in a neighbourhood. The kernel density method used to analyze the dengue density cases in this study. Conceptually a smoothly curved surface over each point is fitted. At the point position, the surface value is the maximum and decreases with increasing distance from the point, reaching zero at the point distance from the point at the Search radius. The density is determined at each output raster cell by adding values for all kernel surfaces where the raster cell core is overlaid [29].

The following formulas define how the Kernel density for points is calculated and how the default search radius is determined within the Kernel density formula.

The following formula determines the predicted density at a new $(x, y)$ location: (see Formula 1 in the Supplementary Files)

\section{Results}

Based on the results of the land-use map overlay with dengue cases, the study area showed a $100 \%$ concentration occurred in the built-up area (Table 1). The built-up area is further subdivided into five sectors according to the first land-use classification, namely industry, infrastructure and utilities, public and commercial institutions, facilities and housing. However, according to the data provided, the multistorey housing area is undervalued in infrastructure and utilities. The results in (Table 2) show that infrastructure and utilities are the most significant areas of dengue fever cases in Bangi town.

Table 1: Dengue cases in different land-use type

\begin{tabular}{lllll}
\hline Land-use Type & \multicolumn{4}{l}{ Year } \\
\cline { 2 - 5 } & 2014 & 2015 & 2016 & 2017 \\
\hline Water body & 0 & 0 & 0 & 0 \\
Transportation & 0 & 0 & 0 & 0 \\
\hline Agriculture & 0 & 0 & 0 & 0 \\
\hline Built-up & 1255 & 1968 & 1407 & 1687 \\
\hline Shrub/ forest & 0 & 0 & 0 & 0 \\
\hline Total & 1255 & 1968 & 1407 & 1687 \\
\hline
\end{tabular}

Table 2: Dengue Cases in Built-up Sectors 


\begin{tabular}{lllll}
\hline Built-up sector & \multicolumn{5}{l}{ Year } & \\
\cline { 2 - 5 } & 2014 & 2015 & 2016 & 2017 \\
\hline Industry & 84 & 97 & 129 & 110 \\
Infrastructure and Utility & 744 & 1283 & 837 & 1136 \\
\hline Institution and Public Facilities & 108 & 118 & 163 & 135 \\
\hline Comercial & 142 & 262 & 152 & 176 \\
\hline Housing & 176 & 208 & 126 & 130 \\
\hline Total & 1254 & 1968 & 1407 & 1687 \\
\hline
\end{tabular}

Spatial distribution conducted based on dengue cases locality reported in the year 2014 found that from 1255 positive cases, most of the dengue cases scattered in the east of study site and occurred in a builtup area in Section 3 and 7 in Bandar Baru Bangi (Figure 2). Kernel density analysis was carried out to find the' hot spot' for dengue cases in Bandar Baru Bangi town (Figure 3). The field marked from green to red gradient indicates from the lowest to highest dengue occurrence rate, which formed the hotspot on the specific areas in the region. The density value for dengue cases reported is between 0 to 491 points per square kilometre with multiple centralized high densities. The highest density value for dengue cases in the year 2014 was between 420 to 491 points per square kilometre observed to be intensed on the northeast of the study site, with margin spreads to the north and south from the hotspot. Another two separated centres with density value from 280 to 350 points per square kilometre discovered on the west and southeast of Bandar Baru Bangi town, with more significant margin from the southeast centre.

Figure 4 shows the spatial distribution of dengue cases locality reported in the year 2015 in Bandar Baru Bangi town with 1968 cases, the highest number of cases compared to another study period (Figure 4). The same pattern of dengue cases scattered in the east of study site as the previous year observed but with higher frequency and covered more sub-district which are in Section 3, 7, 8, 15, and Section 16 of Bandar Baru Bangi town. Most of the infected area is a high population density and residential area. Kernel density analyzed that the density value for dengue cases reported in the year 2015 is between 0 to 637 points per square kilometre with more centralized high density from the year 2014 (Figure 5). The highest density value for dengue cases in the year 2015 was between 605 to 706 points per square kilometre observed to be concentrated on the northeast of the study site, with margin stretched to the north, south and west from the hotspot. Two adjacent centres with density value from 504 to 605 points per square kilometre discovered on the southeast of Bandar Baru Bangi town, with more significant margin extended to the north of study area. Another two discrete centres observed at the northeast and west of study site with density value 403 to 504 points per square kilometre with a smaller margin than the rest. 
Spatial distribution of dengue cases locality reported in the year 2016 in Bandar Baru Bangi town shows a significant decline in the year 2016 with 1407 cases (Figure 6). Hence, the concentration of dengue cases covered less sub-district in the study site, which is in Section 3, 7 and 15 of Bandar Baru Bangi. Kernel density analysis found that the density value for dengue cases reported in the year 2016 is between 0 to 406 points per square kilometre with more diverse centralized high density compared to the year 2015 (Figure 7). The highest density value for dengue cases in the year 2016 was between 348 to 406 points per square kilometre observed forming two separate centres on the lower side of the study site, with margin extended to the north from the hotspot. One of the centres developed another discrete centre to the north direction with a lower density value of 174 to 232 points per square kilometre. A newly emerged centre with density value from 290 to 348 points per square kilometre spotted on the west of Bandar Baru Bangi town, with margin expanded to the southwest of study area. The density value of 232 to 290 points per square kilometre centred at the northeast of study site with margin bordered to the north of study area.

Distribution of dengue cases in the year 2017 increase spatially in Bandar Baru Bangi town with 1687 cases reported (Figure 8). Again, most of the dengue cases located in the housing area in Section 3, 4, 15 and 16 of Bandar Baru Bangi town. Kernel density analysis figured that the density value for dengue cases reported in the year 2017 is between 0 to 637 points per square kilometre (Figure 7). The highest density value for dengue cases in the year 2017 is between 546 to 637 points per square kilometre observed to be centralized at the northeast of the study site, which is also the only hotspot observed. A density value from 364 to 455 points per square kilometre identified below the hotspot, with margin stretched to the northwest of the study area.

\section{Discussion}

Globally, the growing urbanization resulted in humans and non-humans living in close contact, which could increase the risk of infectious diseases, including vector-borne diseases. Rapid urban growth with extensive land-use change processes induced mosquito breeding environment. Developing new township and infrastructure, along with population growth needs, will increase dengue cases.

Kernel density analysis is essential to facilitate the authorities on focusing vector control programme towards on recurrent area of dengue cases hotspot. One of the frequent hotspots occurred from the year 2014 to 2017 was detected at the northeast of Bandar Baru Bangi town, specifically in Section 7. As a town that is experiencing rapid housing development, the developer-focused on high rises residential such as apartments and flats to accommodate a larger group of households. Therefore, it is found that there are three separate apartments in Section 7 with active dengue cases hotspot along the study period [33]. This situation is in line with a study that higher dengue cases arise from interconnected houses compared to single landed residential [35]. The same hotspot pattern observed on the east and southeast 
of Bandar Baru Bangi town especially in Section 3 and Section 4 during study period found that recurrent dengue fever cases derived among residents living in rows of terrace houses [33]. This housing area is located adjacent to the Langat River. Thus, extensive vegetative area on the river bank may provide ample breeding sites for Aedes mosquitoes and eventually contribute to the high dengue fever incidence in the neighbourhood. Apart from built-up factor, a local lifestyle of the society also contributes to the dengue incidence in that area [36]. Night markets in Bandar Baru Bangi that operate almost every day on different location around the residential area caused waste and trash to pile up after working hours, which then only to be clean up on the next morning by the authority [37]. There is a possibility that that trash to be carried away by the wind or rain before it is clean up, thus increase the probability of turning into Aedes breeding sites [38-41]. Therefore, local hygiene is also important to combat dengue incidence in the neighbourhood.

Further increase in dengue cases will impede the growth of Bandar Baru Bangi urbanization in the future. This is because of the higher the rate of dengue infection, the lower the livability of the area [24]. Thus new methods for controlling dengue fever targeted at frequent hotpot locality are increasingly needed. Malaysia had some significant initiatives on dengue control to manage this problem. Since dengue cases often occurred in the housing area, the use of Temefos in large water containers is practised nationwide to reduce the populations of Aedes larvae used in community programs.

\section{Conclusions}

This study conducted discovered that dengue cases show the highest density for a hotspot in the year 2015, from 605 to 706 points per square kilometre in residential and industrial areas of Bandar Baru Bangi. Meanwhile, the lowest density value for dengue hotspot was found in the year 2016 with 348 to 406 points per square kilometre. Hotspots appeared persistently on the east side of the study area along the study period where that shows the residential area of Bandar Baru Bangi is concentrated compared to the industrial area on the west side of the town. Thus, this study also suggests that there are numerous potential Aedes breeding sites in the residential area of Bandar Baru Bangi, which contributed by the abundance of the vegetative area among the neighbourhood and their local lifestyle.

The government should enhance their effort, especially on raising awareness to the public on maintaining the cleanliness of the environment to prevent the spread of dengue in urban areas. Contractors and labourers should dispose of all stagnant water in the construction site to eliminate dengue. With the information stored in the GIS, various actions and precautions can be taken in areas affected by dengue. Existing databases must be carefully maintained to reduce dengue infections in the future. Preventive measures need to be enhanced to improve the future livability of the population.

\section{Declarations}

\section{Ethics approval and consent to participate}


Not applicable.

\section{Consent for publication}

Not applicable.

\section{Availability of data and materials}

Data supporting the conclusions of this article are included within the article. The datasets used and analyzed during the present study are available from the Ministry Of Health Malaysia upon reasonable request.

\section{Competing interests}

The authors declare that they have no competing interests.

\section{Funding}

This research was supported by Universiti Kebangsaan Malaysia (UKM) under the project "Application of GIS in the Spread Trend of Dengue in the Liveability City, Bangi Selangor", grant number GGPM-2018-030. The content expressed in this paper is solely the responsibility of the authors and does not necessarily represent the official views of the UKM. The UKM was not involved in the writing of this manuscript or in the decision to submit the paper for publication.

\section{Authors' contributions}

NAM designed and supervised the study, acquired the funding, provided project administration, proposed methodology, and carried out data acquisition with NMN. MRR and SZSZ review and validated the manuscript. NMN analyzed the data, performed the statistical analysis, and wrote the manuscript drafted by NAM. All authors read and approved on the final manuscript.

\section{Acknowledgements}

Thanks to the Malaysian Ministry of Health and PlanMalaysia for the data provided.

\section{References}

1. Shaharudin I, Abdul-Samad H, Abdul-Hadi HS. Urban Livability: Relationship between Urban Physical Morphology and Livability of Area. Akademika 2010; 79, 19 - 42.

2. Economic Transformation Programme: A Roadmap for Malaysia. Chapter 5, Developing Greater Kuala Lumpur/Klang Valley as an Engine of Economic Growth, 2012. Accessed 3 June 2020.

3. Shaharudin I, Abdul-Samad H, Abdul-Hadi HS, Rainis R. Neighbourhood Expansion and Urban Livability in Seremban Municipality Area, Malaysia. Malaysian Journal of Environmental Management 2010; 11(1), 37-47. 
4. Asgarzadeh, M., Lusk A., Koga T., Hirate K. Measuring oppressiveness of streetscapes. Landsc. Urban Plan. 2012; 107, 1-11.

5. Chen TT, Hui ECM, Lang W, Tao L. People, recreational facility and physical activity: new-type urbanization planning for the healthy communities in China. Habitat Int. 2016, 58, 12-22.

6. Rohani A, Suzilah I, Wan-Najdah WM A, Topek O, Mustafakamal I, Lee HL. Factors determining dengue outbreak in Malaysia. PLoS ONE 2018; 13, e0193326, DOI:10.1371/journal.pone.0193326.

7. Noor Afizah A, Mohd Arif AK, Nazni WA, Lee HL. Ovitrap Surveillance of Aedes aegypti and Aedes albopictus in Dengue Endemic Areas in Keramat and Shah Alam, Selangor in 2016. International Medical Journal Malaysia 2018; Volume 17, No. 3.

8. Basar S, Mohd Nawi MN, Ismail Z. Spatial analysis monitoring on dengue in Malaysia: From the perspective of the construction industry. Malaysian Construction Research Journal 2018; Special Issue, Vol. 3, No. 1.

9. Kamis A, Choy LK. Aplikasi GIS dalam penilaian kawasan berisiko tinggi wabak denggi di Semenanjung Malaysia tahun 2016. GEOGRAFIA Online, Malaysian Journal of Society and Space 2018; 14, Issue 1 (41-56), e-ISSN 2680-2491.

10. Nik Ruzman NSL, Abdul Rahman H. The association between climatic factors and dengue fever: A study in Subang Jaya and Sepang, Selangor. Malaysian Journal of Public Health Medicine 2017; Special Volume (1): 140-150.

11. Hasnan SNA, Che Dom N, Abd Latif Z, Madzlan F. Surveillance of Aedes mosquitoes in different residential types in central zone of Shah Alam, Selangor. Asian Pac J Trop Dis 2017; 7(6): 332-340.

12. Ibrahim N, Md. Akhir NS, Hassan FH. Using clustering and predictive analysis of infected area on dengue outbreaks in Malaysia. Journal of Telecommunication, Electronic and Computer Engineering 2017; e-ISSN: 2289-8131 Vol. 9 No. 2-12.

13. Mohd Hazrin, Hiong HG, Jai N, Yeop N, Muhammad Hatta, Paiwai F, Joanita S, Othman W. Spatial Distribution of Dengue Incidence: A Case Study in Putrajaya. Journal of Geographic Information System 2016; 8, 89-97.

14. Rozilawati H, Tanaselvi K, Nazni WA, Mohd Masri S, Zairi J, Adanan CR, Lee HL. Surveillance of Aedes albopictus Skuse breeding preference in selected dengue outbreak localities, Peninsular Malaysia. Tropical Biomedicine 2015; 32(1): 49-64.

15. Ramlee SNS. Studies of Breeding Habitats and Seasonal Occurrence of Mosquitoes in Putrajaya and Kuala Selangor, with Laboratory Experiments of Guppies and Dragonfly Nymphs as Potential Biocontrol Predators Against Mosquito Larvae. Doctor of Philosophy Dissertation, University of Malaya, Malaysia, 2015.

16. Ling CY. Dengue Disease in Malaysia: Vulnerability Mapping and Environmental Risk Assessment. Master's Dissertation, Humboldt University of Berlin, Berlin, Germany, 28 April 2015.

17. Aziz S, Aidil RM, Nisfariza MN, Ngui R, Lim YAL, Wan Yusoff WS, Ruslan R. Spatial density of Aedes distribution in urban areas: A case study of breteau index in Kuala Lumpur, Malaysia. $J$ Vector Borne Dis 51 2014; pp. 91-96. 
18. Ling CY, Gruebner O, Krämer A, Lakes T. Spatio-temporal patterns of dengue in Malaysia: combining address and sub-district level. Geospatial Health 9(1), 2014; pp. 131-140.

19. World Health Organization. Dengue and Severe Dengue. Retrieved from the World Health Organization. https://www.who.int/news-room/fact-sheets/detail/dengue-and-severe-dengue. Accessed 17 November 2019.

20. Ministry of Health Malaysia. Kenyataan Akhbar Khas Ketua Pengarah Kesihatan Malaysia Berkenaan Situasi Semasa Demam Denggi, Zika Dan Chikungunya Di Malaysia Tahun 2019 Dan Inisiatif KKM Untuk Memerangi Denggi Tahun 2020. http://www.moh.gov.my/index.php/database_stores/store_view_page/21/1290. Accessed 29 April 2020.

21. Ministry of Health Malaysia. Kenyataan Akhbar KPK Mengenai Situasi Denggi, Chikungunya dan Zika13_2020. http://www.moh.gov.my/index.php/database_stores/store_view_page/21/1462. Accessed 29 April 2020.

22. Khormi HM, Kumar L, Elzahrany RA. Modeling Spatio-temporal risk changes in the incidence of dengue fever in Saudi Arabia: A geographical information system case study. Geospatial Health. $2011 ; 6,77-84$.

23. Amrruthraj R, Athul M, Yogeswari S. An entomological analysis on the prevalence of dengue vectors in urban areas of Ernakulam district, Kerala, India. Journal of Entomology and Zoology Studies, 2019; 7(6), 1115-1121.

24. Abd Majid N, Nazi N, \& Mohemed AF. Distribution and spatial pattern analysis on dengue cases in Seremban District, Negeri Sembilan, Malaysia. Sustainability, 2019; 11(13). https://doi.org/10.3390/su11133572.

25. Bouzid M, Colon-Gonzalez FJ, Lung T, Lake IR, Hunter PR. Climate change and the emergence of vector-borne diseases in Europe: Case study of dengue fever. BMC Public Health, 2014; 14, 781.

26. Nuriah Abd Majid \& Rozimah Muhamad Rasdi. 2019. Distribution and spatial pattern analysis on dengue cases in Bangi, Selangor, Malaysia. International Conference On Social Science, Art, Business and Education (ICSABE): 43 - 47.

27. Bhoomiboonchoo P, Gibbons RV, Huang A, Yoon IK, Buddhari D, Nisalak A. The spatial dynamics of dengue virus in Kamphaeng Phet, Thailand. PLoS Negl. Trop. Dis. 2014; 8, e3138.

28. Rojas LI, Barcellos C, Peiter P. Utilizaçäo de mapas no campo da epidemiologia no Brasil reflexöes sobretrabalhos apresentados no IV Congresso Brasileiro de Epidemiologia. Inf. Epidemiol. Sus. 1999; 8, 27-35.

29. 2018. https://desktop.arcgis.com/en/arcmap/10.3/tools/spatial-analyst-toolbox/how-kernel-densityworks.htm. Accessed 10 January 2020.

30. Nuriah Abd Majid, Ruslan Rainis, Ahmad Fariz Mohamed. Spatial analysis of development pressure in the Langat Basin, Selangor, Malaysia. IOP Conf. Ser.: Earth Environ. Sci. 2018; 169012016.

31. Department of Statistics Malaysia. Population distribution by local authority areas and mukims. Population and housing census of Malaysia. 2010. 
32. Mutheneni SR, Mopuri R, Naish S, Gunti D, Upadhyayula SM. Spatial distribution and cluster analysis of dengue using self-organizing maps in Andhra Pradesh, India, 2011-2013. Parasite Epidemiol. Control 2018; 3, 52-61.

33. Senarai Lokaliti hotspot Wabak Denggi di Malaysia. http://www.data.gov.my/data/ms_MY/dataset/senarai-lokaliti-hotspot-wabak-denggi-di-malaysia. Accessed 29 April 2020.

34. Jabatan Perancangan Bandar dan Desa. Data Digital; Jabatan Perancangan Bandar dan Desa: Kuala Lumpur, Malaysia, 2017.

35. Umor S, Mokhtar M, Surip N, Ahmad A. Generating a dengue risk map (DRM) based on environmental factors using remote sensing and GIS technologies. Proceedings of the Asian association on remote sensing. 28th Asian Conference on Remote Sensing. 2007; 2: 867-881.

36. Mohiddin A, Jaal Z, Md-Lasim A, Dieng H, Zuharah WF. Assessing dengue outbreak areas using vector surveillance in north east district, Penang Island, Malaysia. Asian Pac. J. Trop. Dis. 2015; 5 , 869-876.

37. Majlis Perbandaran Kajang. Peluang Perniagaan : Halaman 3 dari 7. http://www.mpkj.gov.my/ms/perniagaan/pembangunan-ekonomi/peluang-perniagaan/page/0/2. Accessed 30 April 2020.

38. Samuel PP, Thenmozhi V, Nagaraj J, Kumar TD, Tyagi BK. Dengue vectors prevalence and the related risk factors involved in the transmission of dengue in Thiruvananthapuram District, Kerala, South India. J Vector Borne Dis 2014; 51: 313-9.

39. Mariappan T, Thenmozhi V, Udayakumar P, Bhavaniumadevi V, Tyagi BK. An observation on breeding behaviour of three different vector species (Aedes aegypti Linnaeus 1762, Anopheles stephensi Liston 1901 and Culex quinquefasciatus Say 1823) in wells in the coastal region of Ramanathapuram District, Tamil Nadu, India. Int J Mosq Res 2015; 2(2): $42-4$.

40. Nkwachukwu Ol, Chima $\mathrm{CH}$, Ikenna AO, Albert L. Focus on potential environmental issues on plastic world towards a sustainable plastic recycling in developing countries. Int J Ind Chem 2013; 4: 34.

41. Raharimalala FN, Ravaomanarivo LH, Ravelonandro P, Rafarasoa LS, Zouache K, Tran-Van V. et al. Biogeography of the two major arbovirus mosquito vectors, Aedes aegypti and Aedes albopictus (Diptera, Culicidae), in Madagascar. Parasit Vector 2012; 5: 56.

\section{Figures}




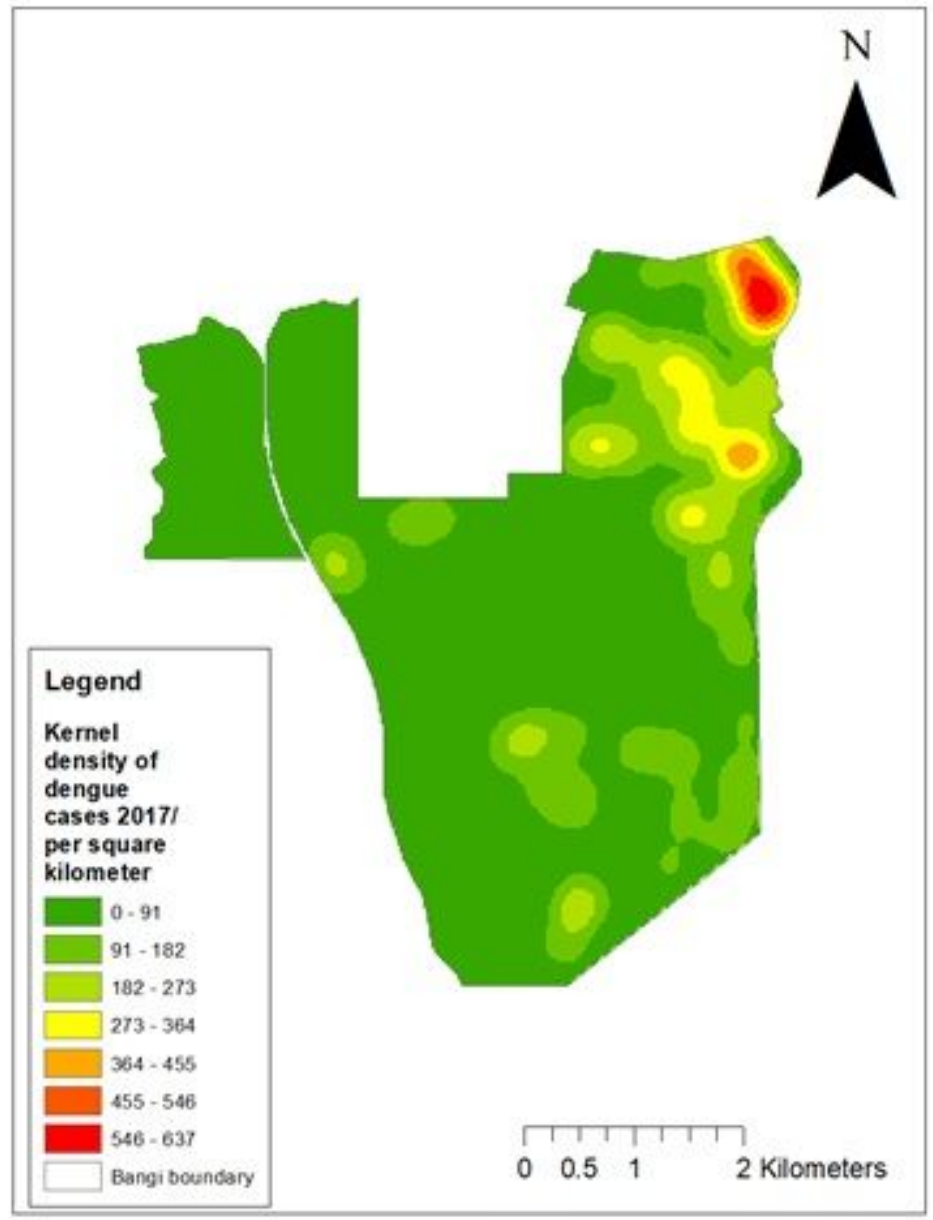

Figure 1

Kernel Density 2017

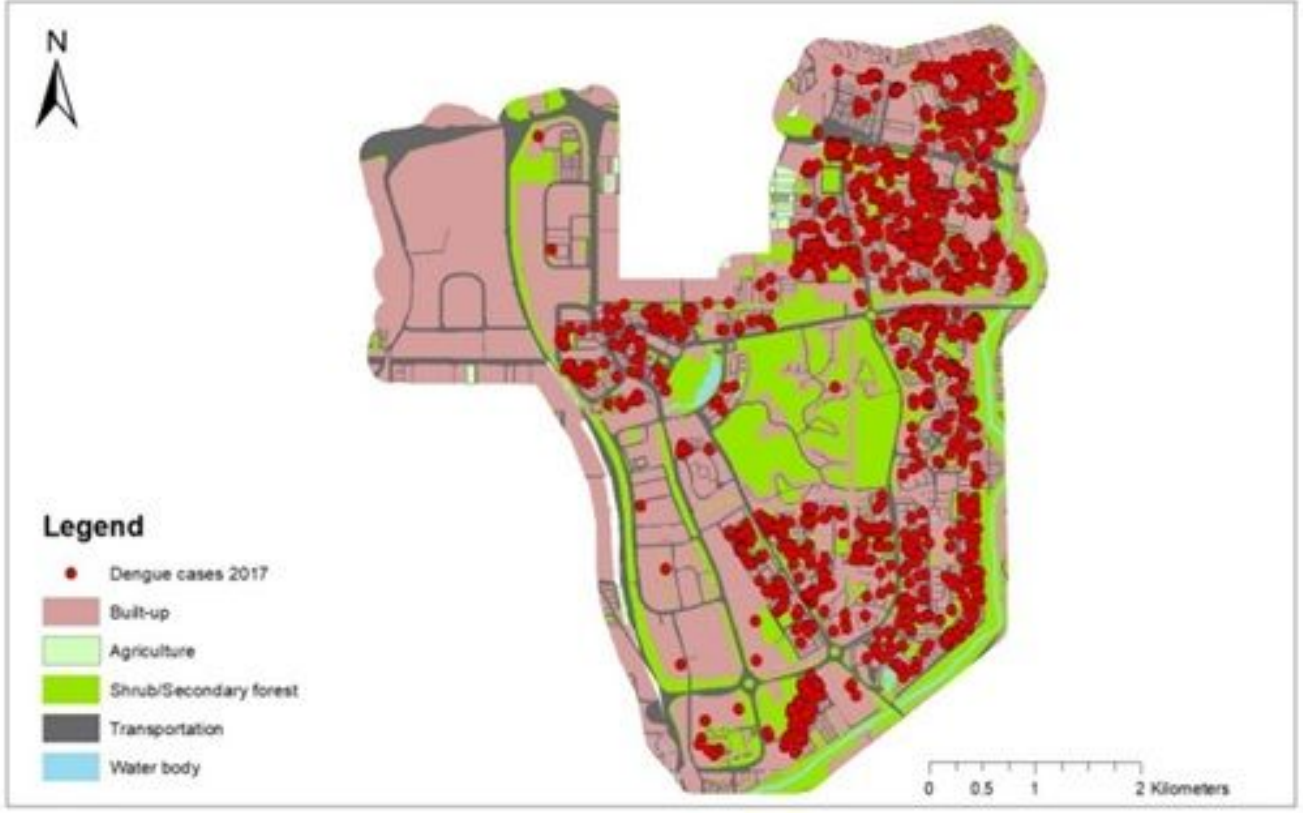

Figure 2 


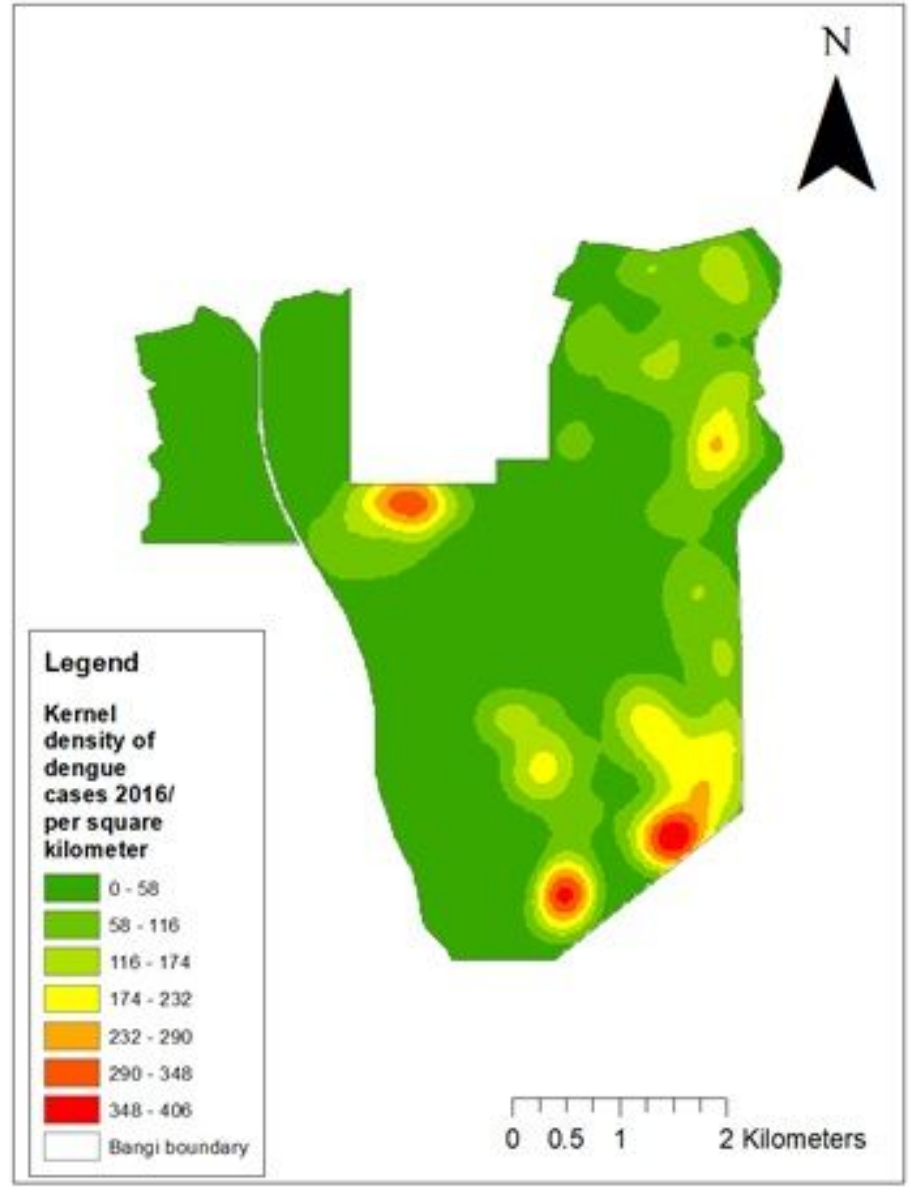

Figure 3

Kernel Density 2016

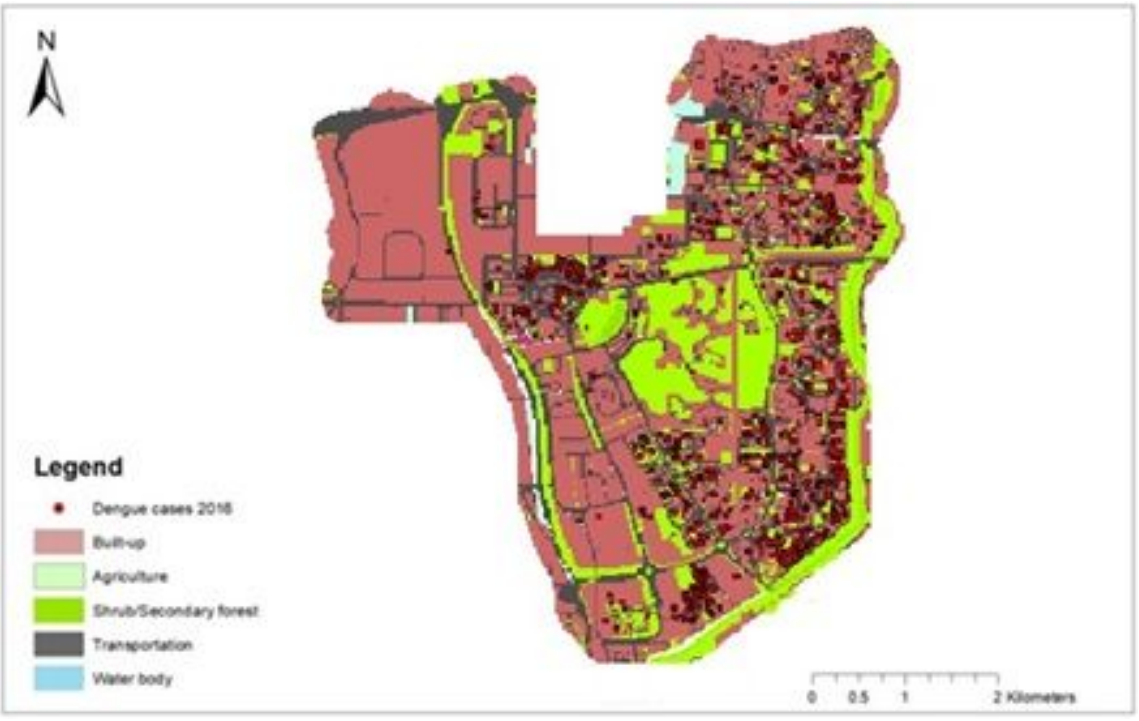

Figure 4

Land use 2016 


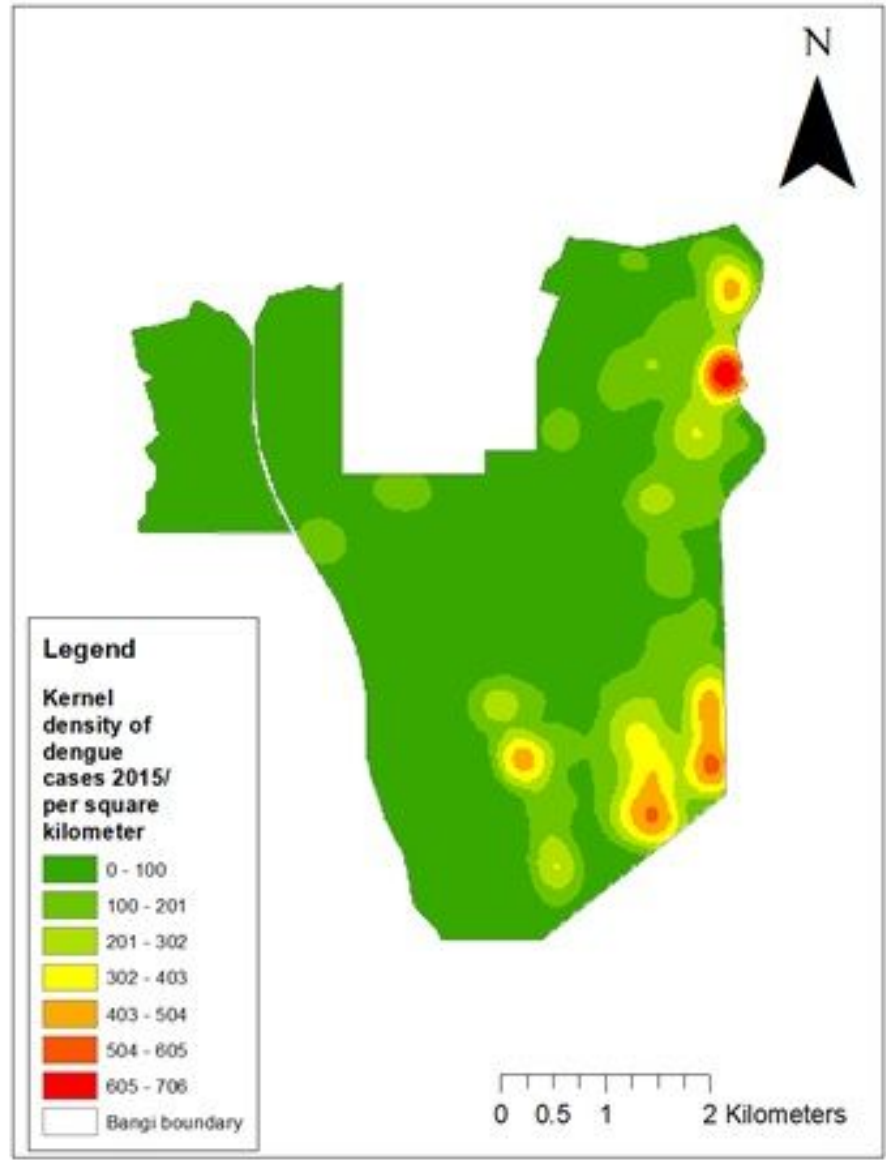

\section{Figure 5}

Kernel Density 2015

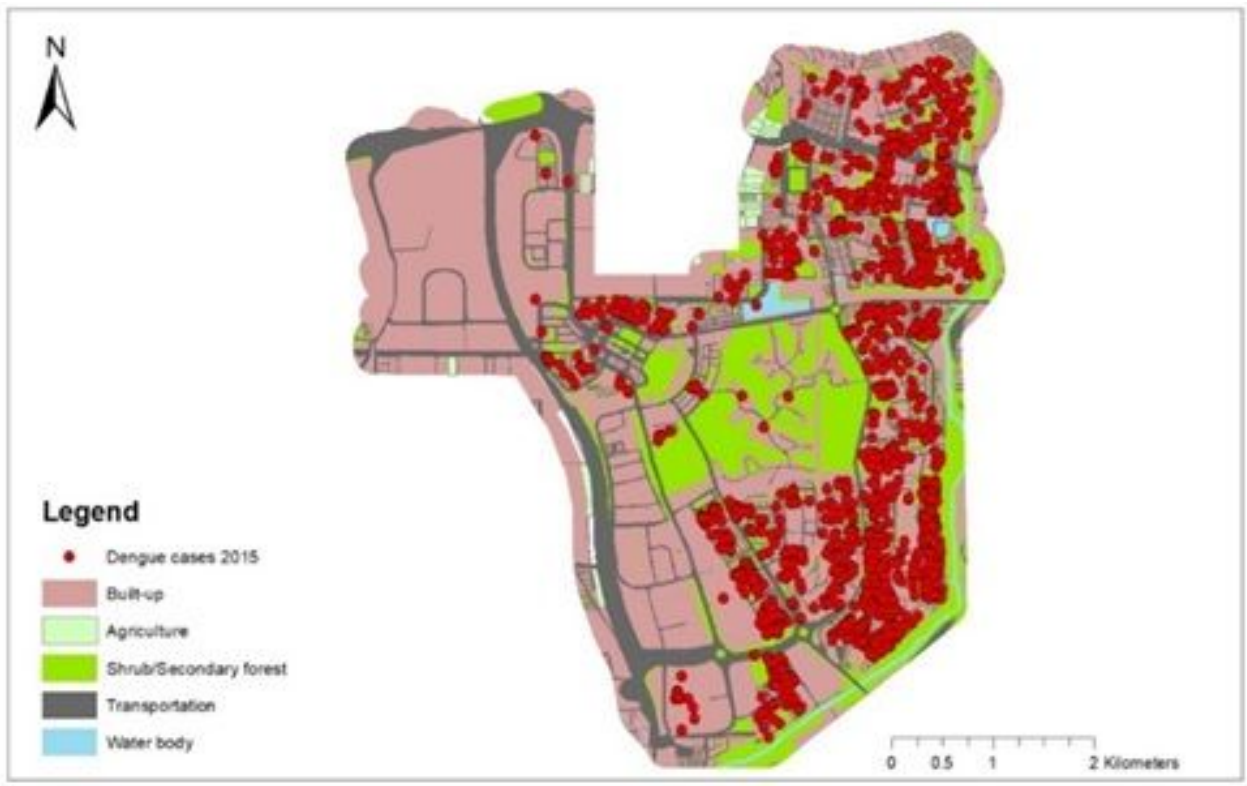

Figure 6

Land use 2015 


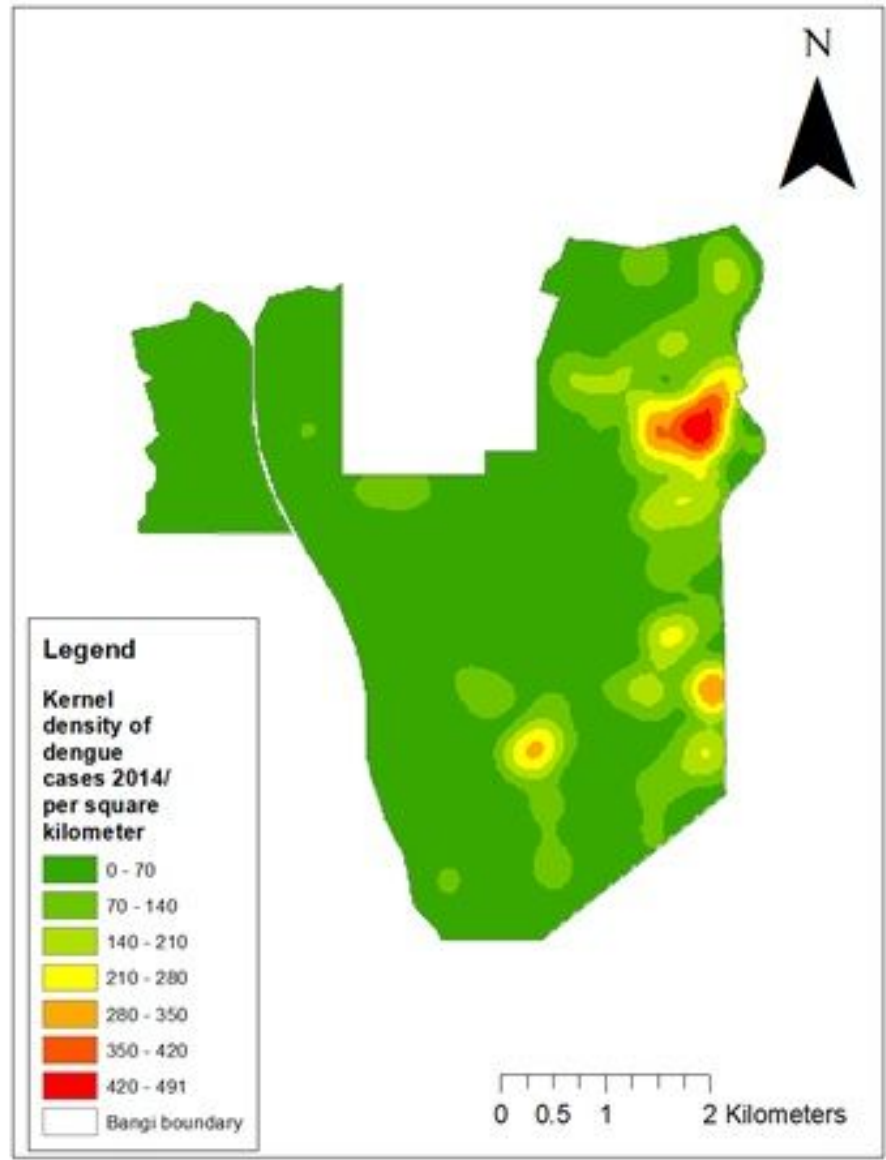

Figure 7

Kernel Density 2014

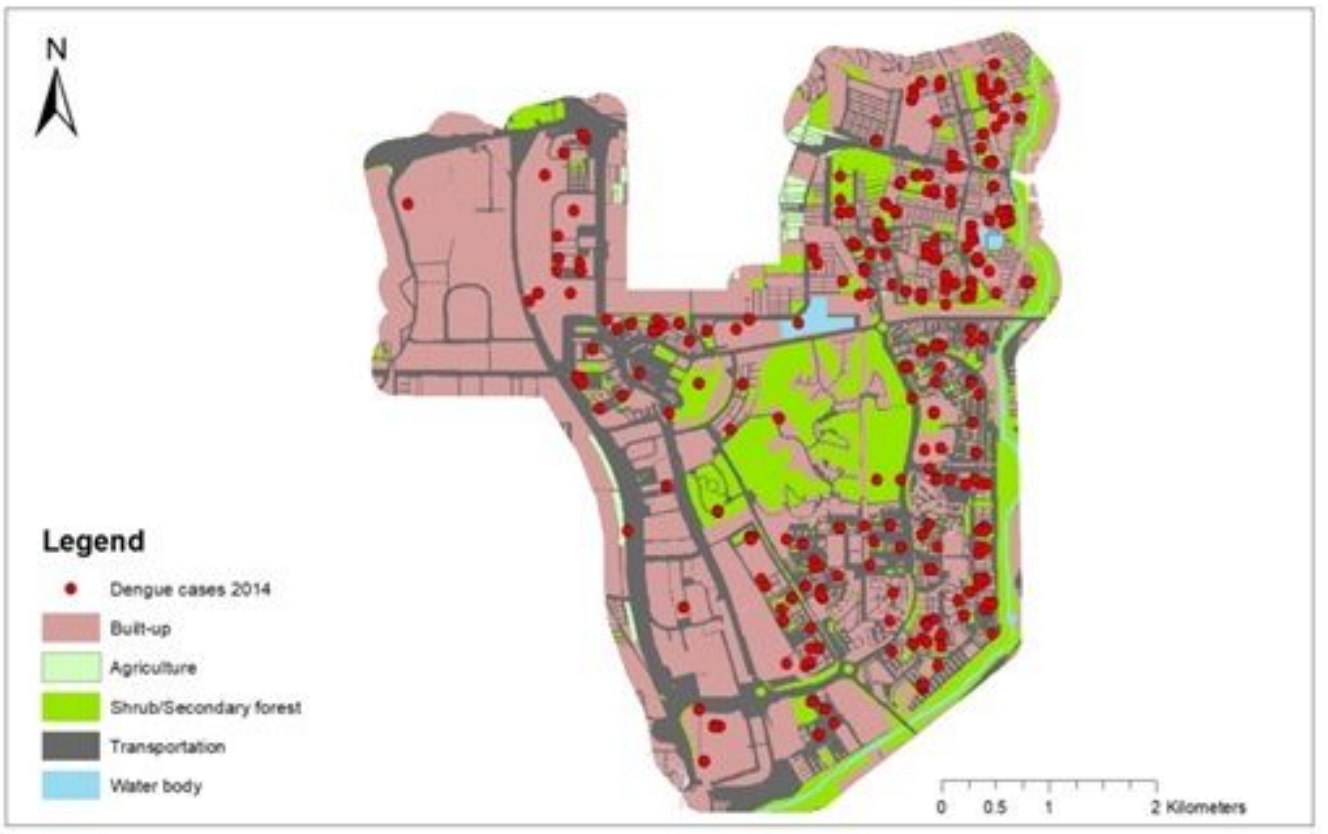

Figure 8

Land use 2014 


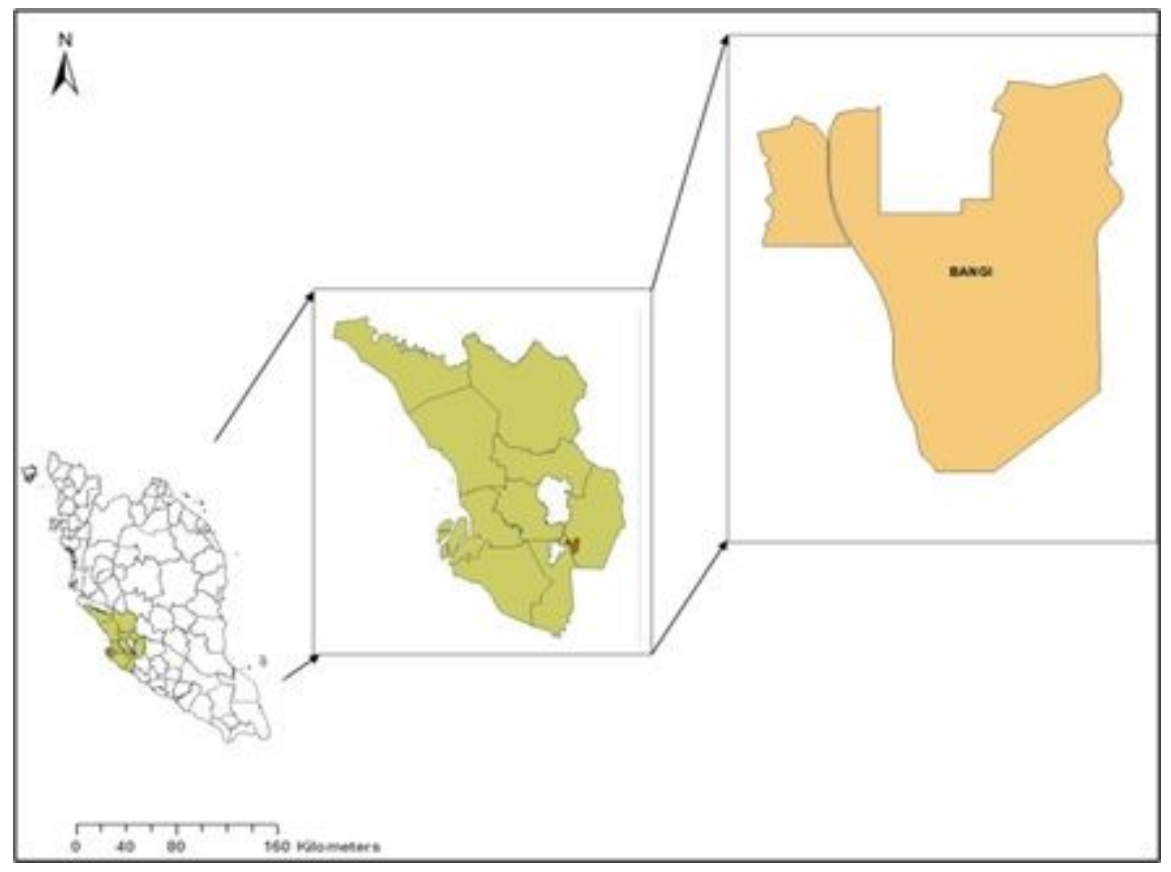

Figure 9

Study Site

\section{Supplementary Files}

This is a list of supplementary files associated with this preprint. Click to download.

- Formula1.pdf 